\title{
THE BRITISH COTTON INDUSTRY RESEARCH ASSOCIATION
}

\author{
OPEN DAYS AT THE SHIRLEY INSTITUTE
}

\section{$\mathrm{T}$} HE fortieth annual general meeting of the British Cotton Industry Research Association was held at the Shirley Institute on October 22, with the chairman of the Association, Mr. N. G. MeCulloch, presiding. In his address Mr. MeCulloch said that he wished to reiterate a view that he had many times expressed, that there was an urgent need in the Lancashire textile industry for a much more concentrated and sustained study of the subject of organization and management than had so far been attempted. The Shirley Institute was no stranger to this field of work and had made a number of worthy contributions, but the effort needed intensifying and widening. Mr. MoCulloch also referred to the working party which had been set up to consider the problems involved in the proposed fusion of the Institute with the British Rayon Research Association, and emphasized the importance of this latest move towards rationalizing co-operative research for the Lancashire textile industry.

Mr. J. Lindley, honorary treasurer, in reviewing the statement of accounts for the year, was particularly concerned to emphasize the need for adequate reserves, since expenditure on research could not be turned either off or on like a tap. He pointed out that the general reserves at present were in fact only sufficient to pay the Association's outgoings for rather less than nine months.

At the end of the meeting, Mr. McCulloch announced his forthcoming resignation and tributes were paid both by Mr. Lindley and from the floor of the meeting to his great contribution as chairman for the past ten years.

Dr. D. W. Hill, director of research, then presented his report on the year's work and stressed the consideration which had been given during the year to the need for a research association to follow up its research work with all possible steps to ensure application in mills and works. This was a particular concern of the Institute during the industry's difficult times, and it was reflected, for example, by an increase of 14 per cent in technical inquiries received by the Institute during the preceding year. There was also a need to keep abreast of industrial advances in foreign countries, to which end four teams had been sent to the Continent to visit Holland, Italy, France and Western Germany and to report their experiences to members.

In selecting a few research and development topics for special comment, Dr. Hill mentioned the continuing work for spinners on control of regularity of their intermediate products, and referred to the success of the cop sorting device for condenser spinners. A new programme of work was now starting on winding and beaming, with particular emphasis on the variations in the density of various wound packages. Results of interest to both spinners and weavers should follow the introduction of a new technique involving the use of a radioactive isotope within the package. The work on sizing continued and attention had been paid to, and a device developed for, reducing the hairiness of yarns, particularly those of synthetic fibres. Work on the dry-feed attachment of the automatic size box had reached the point of initiating mill trials. It was impossible, with the limited resources available, to do simultaneous research on all the widely diverse problems of the industry, and it had been decided to devote attention at intervals to the smaller and more specialized sections. At the moment, for example, a fundamental study of the operation of a terry-towel loom was being started.

On the chemical side, Dr. Hill directed particular attention to past history of work at the Institute on bleaching processes, work which had been recently brought up to date by a thorough examination of the mechanism of sodium chlorite as a bleaching agent, which had also produced very valuable technological results. Also for finishers, Dr. Hill reported that a long-term physical study of the action of the raising machine had resulted in the introduction of a new kind of instrumentation in this process which should be of great technical benefit.

As in previous years, the Institute laboratories were open for inspection for two days, when all members of staff were available for consultation.

Spinners were particularly interested in an automatic nep counter, so far only used for research purposes, in which a photoelectric method is used for detecting neps, followed by an electronic counter. A new version of the Shirley opener was also shown, as was a recent further improvement to the pressurepoint system.

In the Weaving Department a large exhibit attracted the attention of members to the widely varied services the Institute could offer them, while another exhibit analysed the major causes of warp breaks during weaving. A stretch regulator, the Shirley loom and the new device for reducing hairiness were also operating. Most interest in this section, however, was raised by the exhibit showing the range of, and methods used in, the investigation being carried out on yarn clearing.

Finishers were given working demonstrations of the flash steamer now commercially available and of the new raising action indicator. A highly important new programme is that on washing efficiency, with the high cost of water and the expense of effluent disposal becoming increasingly serious. Preliminary results already suggest that there will be considerable gains from working in this field.

Fundamental work on the mechanism of the burning of cellulose has started and there were demonstrations both of the production of inflammable tars as intermediate products, and also of the behaviour of existing flame-proofing agents. The use of infra-red absorption analysis for identification of finishes and contaminants was interesting both fundamentally and as an aid to the technologists.

The Institute continues its fundamental investi. gation of the effect on yarn and fabric properties of blending natural and synthetic fibres, and a general display showed the extent to which it is now possible to forecast many of these properties from a previous knowledge of fibre properties.

Old and new instruments were in evidence both for research and control purposes. As usual, there was a stand showing the instruments being handled 
by Shirley Developments, Ltd., which, as a result of rapid growth, now shows in its catalogue 30 instruments and 30 mechanical devices.

New instruments for research purposes included a new photomicrographic apparatus designed and made at the Institute, and also a polarizing lustre meter with which it is hoped to interpret how the eye judges lustre.

It was encouraging that a large proportion of the visitors on the open days came with the definite object in mind of seeing how the Institute's work made an impact on their own mill or works.

\section{AGRICULTURAL INSTITUTE OF THE REPUBLIC OF IRELAND DIVISION OF PLANT SCIENCES AND CROP HUSBANDRY}

$\mathrm{T}$ HE establishment, under the Agricultural (An Foras Talúntais) Act, 1958, of the Agricultural Institute of the Republic of Ireland, An Foras Talúntais, was announced in Nature, July 4, 1959. The Institute now announces major developments in the organization of the Division of Plant Sciences and Crop Husbandry. This will provide a wide coverage in the plant sciences field, catering for research in plant pathology, entomology (including nematology), plant breeding, plant protection, plant quality, weed control, and other general aspects of crop husbandry.

Mr. B. Crombie, at present in charge of the Plant Breeding Station of Cómhlucht Siúicre Éireann, Teo. (Irish Sugar Company), at Thurles, Co. Tipperary, has been appointed ehief of this Division. Mr. Crombie, a native of Offaly, gained his B.Agr.Se. degree with honours at the National University of Ireland in 1934 and was awarded a postgraduate scholarship. In 1937 he gained his M.Sc. degree for a thesis on "The Influence of Various Factors on the Time of Ripening of Wheat Varieties". While working under Prof. M. Caffrey, University College, Dublin, Mr. Crombie was responsible for the breeding of the well-known Glasnevin strains of perennial ryegrass and cocksfoot. He had been responsible for the organization of seed-breeding research and developments with Cómhlucht Siúicre Eireann, Teo., giving to the industry sugar-beet seeds of top quality. Mr. Crombie has published papers dealing with his research work in a number of scientific journals. $\mathrm{He}$ comes to his new post with a high reputation not only in plant breeding but also in plant science and crop-husbandry work in general.

By mutual agreement between the Council of An Foras Talúntais and the Industrial Research Committee of the Institute for Industrial Research and Standards, the facilities and equipment of the Cereals Laboratory at the latter Institute have been made available to An Foras Taluntais. This laboratory will devote special attention to the question of baking quality in wheat in relation to soil, manurial, climatic, varietal and cultural conditions, while in addition undertaking research on quality in other cereals. The general supervision of this laboratory for An Foras Talúntais will be in the hands of the director of the Institute for Industrial Research and Standards, Mr. D. T. Flood. Mr. P. A. Spillane has been appointed a senior research officer on the staff of An Foras Talúntais and will be head of the laboratory. Other appointments to this Unit are those of Miss $\mathbf{H}$. McGovern as research officer and Misses K. McGrath and E. Cooper as technicians. Mr. Spillane graduated from University College, Dublin, with honours in physics and chemistry in 1936. He has a wide experience of research and general operational work in the flour-milling industry and is the author of a number of scientific papers dealing with this work.
It has been agreed in principle between the Board of Cómhlucht Siúicre Érireann, Teo., and the Council of An Foras Talúntais that the sugar-beet breeding research facilities at Thurles and the Nematology Laboratory at Carlow of the Irish Sugar Company will be integrated with An Foras Talúntais. These centres have already been placed under the scientific direction of An Foras Talúntais pending the conclu. sion of arrangements by the staffs of the organizations concerned. This arrangernent places at the disposal of the Agricultural Institute the scientific staff and extensive offices, laboratory and greenhouse facilities and equipment which have been developed at these centres over a number of years. While the sugar-beet seed research programme will be continued and expanded at Thurles by An Foras Talúntais on behalf of Cómhlucht Siúicre Éireann, Teo., this centre will also act as headquarters of the Division, with the resulting development of research services in general plant science work apart from those needed for sugar-beet research.

The nematology laboratory at Carlow which provides well-developed facilities for this sphere of research will also be used in the general research programme of the Institute. Dr. J. J. Duggan has been appointed senior research officer in charge of the Nematology Unit of the Institute now located at University College, Dublin. Dr. Duggan is well known for his research work in nematology on which he has published a number of scientific papers, and the Unit at Carlow is now under his scientific direction.

A Plant Pathology Unit has been established. Dr. J. B. Loughnane, Department of Plant Pathology, University College, Dublin, is acting as adviser for this aspect of the activities of the Institute. Mr. $\mathrm{P}$. Cunningham and Mr. C. Comerford are now working under Dr. Loughnane in the Plant Pathology Unit, while Mr. T. E. Mulligan, previously on the staff of the Rothamsted Experimental Station, joined the staff of the Unit on October l. Associated Seed Growers, Ltd., have generously offered a grant for the investigation of the diseases of a number of crops such as kale and mangels. This offer has been accepted by the Council of the Institute and investigations are already under way.

Arrangements are also being completed for placing an Applied Plant Genetics Research Unit at the Kells Ingram Farm of the University of Dublin, working under the general direction of Mr. G. W. P. Dawson, head of the new Department of Genetics, Trinity College, Dublin. This Unit will deal with some of the more practical aspects of plant genetics. Mr. V. Connolly has been appointed research officer in this Division. Arrangements are proceeding with the organization of the other departments of the Division, and it is hoped to have a full research programme under way during the coming year. 